\title{
Faktor individu dan lingkungan dengan citra tubuh pada santri putri di pondok pesantren
}

Individual and environmental factors toward body image of female students at religious boarding school

\author{
Labiqotul Fatiyasani ${ }^{1}$, Ika Ratna Palupi ${ }^{1}$, Tjaronosari ${ }^{2}$ \\ 'Departemen Gizi Kesehatan, Fakultas Kedokteran, Kesehatan Masyarakat, dan Keperawatan Universitas Gadjah Mada, Yogyakarta \\ ${ }^{2}$ Jurusan Gizi, Politeknik Kesehatan Kementerian Kesehatan Yogyakarta
}

\begin{abstract}
Background: Perception and judgment against one's own body is called body image. Limited studies have been performed on body image of the population living in boarding schools who has relatively homogeneous environmental characteristics and restricted access towards communication media. Objective: To determine the correlation between individual factors and environmental factors with body image of female students at religious boarding school. Methods: A cross-sectional study was conducted in 142 female students aged 15-19 years old in Islamic Centre Bin Baz (ICBB) boarding school Bantul. Individual factors included nutritional status, nutritional knowledge, and self-esteem, respectively measured by using BMI/age that interpreted using manual from Ministry of Health 2010, multiple choice questionnaire, and Rosenberg Self-Esteem Scale (RSE). Environmental factors encompassed culture, social economic status, and social support, respectively measured by using check lists of parent's ethnics, social economic status questionnaire, Social Support Questionnaire Number (SSQN) and Social Support Questionnaire Satisfaction (SSQS). Body image was measured using CDRS (The Contour Drawing Rating Scale) form. All variables were tested using chi square test and logistic regression. Results: Individual factors that had significant correlations with body image were nutritional status ( $p<0.05$; $R P=1.3 ; 95 \% C I=2.68-2.83)$ and self-esteem $(p<0.05 ; O R=21.3 ; 95 \% C I=3.97-114.3)$. Meanwhile, for environmental factors, they were social economic status $(p<0.05)$ and social support satisfaction $(p<0.05 ; 95 \% C I=0.02-0.95)$. Conclusion: Individual and environmental factors have correlation with body image of female students at religious boarding school.
\end{abstract}

KEY WORDS: boarding school; body image; environment factor; female adolescent; individual factor

\begin{abstract}
ABSTRAK
Latar belakang: Persepsi dan penilaian seseorang tentang bentuk tubuhnya disebut dengan citra tubuh. Permasalahan citra tubuh dan faktor-faktor yang mempengaruhinya belum banyak diteliti pada populasi pondok pesantren yang relatif homogen dan memiliki keterbatasan akses alat komunikasi serta media informasi. Tujuan: Penelitian ini bertujuan untuk mengetahui hubungan antara faktor individu dan lingkungan dengan citra tubuh santriwati pondok pesantren. Metode: Desain penelitian cross sectional dengan jumlah subjek 142 santriwati berusia 15-19 tahun di pesantren Islamic Center Bin Baz (ICBB) Bantul. Variabel faktor individu meliputi status gizi, pengetahuan gizi, dan rasa percaya diri yang masing-masing diketahui dengan indeks IMT/U (Kemenkes RI, 2010), kuesioner pengetahuan gizi dengan tipe multiple choice question (MCQ), dan Rosenberg self-esteem scale (RSE). Variabel lingkungan yaitu budaya, sosial ekonomi keluarga, dan dukungan sosial, masing-masing diketahui dari daftar tilik suku bangsa ayah dan ibu, kuesioner sosial ekonomi, social support questionnaire number (SSQN), dan social support questionnaire satisfaction (SSQS). Variabel citra tubuh diukur dengan formulir the contour drawing rating scale (CDRS). Analisis statistik menggunakan uji Chi-Square dan regresi logistik. Hasil: Variabel faktor individu yang berhubungan dengan citra tubuh yaitu status gizi ( $\mathrm{p}<0,05$; $\mathrm{RP}=1,3 ; 95 \% \mathrm{CI}: 2,68-2,83)$ dan rasa percaya diri $(\mathrm{p}<0,05 ; \mathrm{OR}=21,3 ; 95 \% \mathrm{CI}: 3,97-114,3)$. Variabel faktor lingkungan yang berhubungan dengan citra tubuh adalah sosial ekonomi $(\mathrm{p}<0,05)$ dan dukungan sosial aspek kepuasan dukungan $(\mathrm{p}<0,05 ; 95 \% \mathrm{CI}$ : 0,02-0,95). Simpulan: Faktor individu dan faktor lingkungan berhubungan dengan citra tubuh pada santri putri di pondok pesantren.
\end{abstract}

KATA KUNCI: pondok pesantren; citra tubuh; faktor lingkungan; remaja putri; faktor individu 


\section{PENDAHULUAN}

Masa remaja adalah bagian proses tumbuh kembang yang merupakan peralihan dari masa anak-anak menuju dewasa. Berbagai perubahan terjadi secara fisik maupun mental sehingga masalah gizi dapat muncul pada usia ini. Remaja yang mengalami masalah gizi akan berpengaruh pada kualitas sumber daya manusia (SDM) dan dapat berakibat pada hilangnya generasi muda serta berdampak pada keadaan perekonomian bangsa di masa mendatang (1). Berbagai proses pematangan terjadi pada usia remaja. Pertumbuhan tinggi badan yang mencapai maksimal dan komposisi tubuh berupa otot dan lemak yang terdistribusi pada bagian-bagian tertentu menjadi menarik untuk diperhatikan (2). Di samping itu, remaja juga mengalami perkembangan emosi, sosial, dan intelektual. Pada umumnya, kelompok ini menginginkan kebebasan dalam menentukan pilihan karena pada fase ini mereka belajar untuk mengambil keputusan sendiri (3).

Tumbuh kembang fisik yang begitu cepat membuat remaja memberikan perhatian banyak pada kondisi fisiknya. Perhatian ini tidak lepas dari kondisi perkembangan mentalnya untuk menemukan penghargaan diri dari lingkungan sekitarnya dan pembentukan rasa percaya diri. Hal ini menyebabkan remaja mulai memberikan penilaian terhadap gambaran tubuhnya atas dasar bagaimana lingkungan menilai mereka (3). Lingkungan sangat berperan penting terhadap penilaian citra tubuh. Kondisi keterpaparan media, peran serta keluarga, serta pergaulan dengan teman sebaya dapat memengaruhi cara pandang remaja terhadap kondisi fisik tubuhnya $(4,5)$. Kondisi individu juga dapat memengaruhi penilaian citra tubuh. Studi menunjukkan bahwa citra tubuh negatif lebih banyak ditemukan pada perempuan (6). Hal ini menjadi sangat sensitif pada fase remaja awal yaitu sekitar usia 13-15 tahun (7). Kondisi tersebut menunjukkan bahwa jenis kelamin dan usia memengaruhi persepsi seseorang terhadap citra tubuh. Selain itu, pengetahuan mengenai gizi dan bentuk tubuh ideal juga memengaruhi seseorang dalam menilai ukuran tubuhnya (8).

Penelitian mengenai citra tubuh telah banyak dilakukan pada subjek remaja di Yogyakarta dengan lokasi penelitian di sekolah umum yaitu SMP dan SMA (9, 10). Di sisi lain, penelitian mengenai citra tubuh dan faktor-faktor yang memengaruhinya pada populasi remaja yang menempuh pendidikan di pondok pesantren jarang dijumpai. Pondok pesantren merupakan lembaga pendidikan yang menerapkan sistem asrama dengan peraturan yang ketat mengenai larangan membawa dan menggunakan alat komunikasi selama tinggal di lingkungan tersebut. Keterbatasan akses alat komunikasi dan paparan media massa pada penghuni pondok pesantren yang tergolong pada kelompok usia remaja (santri putri) dapat mempengaruhi pandangan mereka terhadap bentuk tubuh yang ideal, terutama karena penampilan merupakan hal penting pada usia ini. Studi yang dilakukan pada santriwati berusia 15-17 tahun di sebuah pondok pesantren tradisional di Kediri menemukan proporsi ketidakpuasan citra tubuh sebesar $17,92 \%$ dan adanya hubungan bermakna $(\mathrm{p}<0,05)$ antara ketidakpuasan citra tubuh dengan gangguan perilaku makan, gangguan perilaku makan dengan status gizi, dan citra tubuh dengan status gizi (11). Penelitian yang telah dilakukan pada santri putri di pondok pesantren di Indonesia lebih banyak melihat variabel asupan makan, tingkat kecukupan gizi, status gizi, dan kejadian anemia $(12,13,14)$ sedangkan permasalahan citra tubuh belum banyak diteliti. Dengan demikian, penelitian ini bertujuan untuk mengetahui hubungan antara faktor individu dan faktor lingkungan dengan citra tubuh santri putri di pondok pesantren.

\section{BAHAN DAN METODE}

Jenis penelitian analitik non-eksperimen dengan rancangan cross-sectional dilakukan pada bulan Mei - Juni 2016. Penelitian berlokasi di pesantren Islamic Center Bin Baz (ICBB) Bantul yang memiliki aturan ketat dalam penggunaan alat komunikasi berupa telepon genggam, majalah, televisi, dan radio. Populasi penelitian adalah santri putri Madrasah Aliyah ICBB (setingkat SMA). Subjek yang diambil pada penelitian ini sebanyak 142 orang yang diperoleh dengan metode purposive sampling. Kriteria inklusi subjek yaitu berusia 15-19 tahun, berstatus aktif sebagai santri putri Madrasah Aliyah ICBB, telah tinggal di asrama minimal selama satu tahun, dan bersedia mengikuti penelitian. Tidak terdapat kriteria eksklusi subjek dalam penelitian ini. 
Variabel penelitian terdiri dari variabel bebas yaitu faktor individu dan faktor lingkungan serta variabel terikat yaitu citra tubuh. Faktor individu adalah faktor internal yang memengaruhi citra tubuh, terdiri dari status gizi, pengetahuan gizi, dan rasa percaya diri sedangkan faktor lingkungan adalah faktor eksternal yang memengaruhi citra tubuh, terdiri dari budaya, status sosial ekonomi keluarga, dan dukungan sosial.

Variabel status gizi merupakan perbandingan antropometri indeks massa tubuh berdasarkan usia (IMT/U) yang diketahui dari pengukuran berat badan dan tinggi badan yang diinterpretasikan berdasarkan pedoman Kemenkes 2010 menjadi kategori status gizi lebih ( $>+1$ Standar Deviasi/SD); status gizi normal (-2 SD hingga $+1 \mathrm{SD})$; dan status gizi kurang (<-2 SD). Pengetahuan gizi merupakan pemahaman santriwati tentang sumber-sumber zat gizi dalam makanan serta fungsi dan manfaatnya bagi tubuh, diukur menggunakan kuesioner pengetahuan gizi dengan tipe multiple choice question (MCQ) sejumlah 20 soal (15). Pengetahuan gizi dinyatakan baik apabila skor di atas $75 \%$ dari skor maksimum dan kurang untuk skor di bawahnya, penilaian menggunakan skor 1 untuk jawaban benar dan skor 0 untuk jawaban salah. Validasi kuesioner pengetahuan gizi pada penelitian ini dilakukan pada 40 orang siswa dari sekolah yang sama namun bukan merupakan subjek penelitian dan memperoleh 12 butir soal valid dengan nilai koefisien reliabilitas tinggi $(0,73)$. Selanjutnya, rasa percaya diri adalah persepsi santriwati tentang nilai dirinya sebagai manusia, diukur menggunakan kuesioner Rosenberg self-esteem scale (RSE) yang telah diadaptasi dan diterjemahkan dalam bahasa Indonesia dengan nilai reliabilitas tinggi $(0,8504)(16)$. Penilaian rasa percaya diri memiliki rentang skor 0 hingga 3 dengan kategori total skor rendah $(<17)$, normal (17-22), dan tinggi $(>22)$.

Variabel budaya merupakan latar belakang keluarga subjek berupa suku bangsa yang diketahui dari daftar tilik suku bangsa ayah maupun ibu dan dikategorikan menjadi Jawa dan non Jawa. Status sosial ekonomi adalah kedudukan keluarga subjek dalam struktur masyarakat yang dipandang dari segi pendidikan, pekerjaan, pendapatan, kekayaan yang dimiliki, dan jumlah anggota keluarga. Variabel sosial ekonomi diukur menggunakan kuesioner sosial ekonomi dengan nilai reliabilitas tinggi $(0,636)(17)$ dan dikategorikan menjadi tingkat sosial ekonomi rendah (total skor kuesioner $<21$ ), sedang (total skor 21-23), dan tinggi (total skor $>33$ ). Dukungan sosial adalah kontribusi lingkungan keluarga dan teman santriwati dalam memberikan dukungan secara emosional, penghargaan, informasional, dan instrumental yang diukur menggunakan social support questionnaire number (SSQN) untuk mengetahui aspek banyaknya dukungan dan social support questionnaire satisfaction (SSQS) untuk mengetahui aspek kepuasan dukungan. Kedua instrumen penelitian memiliki nilai reliabilitas yang baik sebesar 0,943 dan 0,968 (18). Skor SSQN pada masing-masing butir adalah minimal 0 dan maksimal 9 dengan kategori banyak dukungan (skor $\geq 3$ ) dan sedikit dukungan (skor $<3$ ). Sementara itu, skor SSQS pada masing-masing butir memiliki nilai minimal 1 dan maksimal 4 dengan kategori kepuasan dukungan berupa tidak puas (skor $\leq 2,5$ ) dan puas (

Variabel citra tubuh merupakan persepsi dan penilaian seseorang terhadap penampilan bentuk tubuhnya sendiri. Citra tubuh ditentukan dengan mengukur ketidaksesuaian antara jumlah gambar bentuk tubuh yang menggambarkan kondisi aktual dengan gambaran ideal subjek menggunakan formulir the contour drawing rating scale (CDRS). Formulir ini terdiri dari sembilan gambar kontur tubuh dengan skala underweight tingkat berat (skala 1) hingga sangat overweight (skala 9) dan telah digunakan pada penelitian dengan subjek remaja putri di Yogyakarta serta memiliki nilai reliabilitas yang baik $(0,70)(19)$. Kategori penilaian citra tubuh yaitu negatif (apabila gambar tubuh saat ini berbeda dengan gambar tubuh ideal yang diinginkan) dan positif (apabila gambar tubuh saat ini sama dengan gambar tubuh ideal yang diinginkan).

Instrumen penelitian meliputi informed consent, kuesioner terstruktur, dan alat ukur antropometri berupa alat ukur tinggi badan (microtoise) dan timbangan berat badan digital yang telah dikalibrasi. Pengumpulan data dilakukan di asrama pada hari libur sekolah oleh peneliti bersama 7 orang enumerator yaitu mahasiswa Program Studi Gizi Kesehatan UGM yang telah mengikuti mata kuliah penilaian status gizi dan memperoleh pengarahan dari peneliti. Analisis data menggunakan uji Chi-Square dengan tingkat kemaknaan (p) sebesar 0,05. Pada hasil uji bivariat yang menunjukkan tingkat signifikansi kurang 
dari 0,25 , dilakukan analisis multivariat menggunakan uji regresi logistik untuk mengetahui faktor-faktor yang secara bersama-sama memengaruhi citra tubuh. Penelitian ini telah memperoleh surat izin kelayakan etik dari Komite Etik Fakultas Kedokteran Universitas Gadjah Mada dengan nomor KE/FK/504/EC/2016.

\section{HASIL}

Tabel 1 menunjukkan bahwa mayoritas subjek berusia kurang dari 18 tahun $(81,7 \%)$ dengan rerata usia 16,7 tahun. Subjek berasal dari berbagai wilayah di Indonesia tetapi mayoritas berasal dari Jawa $(62,7 \%)$. Pendidikan terakhir ayah (46,4\%) dan ibu (42,3\%) subjek adalah tamat diploma/sarjana sehingga memberikan gambaran bahwa sebagian besar subjek memiliki latar belakang orang tua berpendidikan tinggi. Seperempat subjek (24,6\%) berstatus gizi lebih dan sisanya berstatus gizi normal. Rerata status gizi subjek berada pada kisaran normal yaitu $21,1 \pm 3,2 \mathrm{~kg} / \mathrm{m}^{2}$.

Hasil pada Tabel 2 diketahui bahwa sebanyak $80,3 \%$ subjek (114 orang) memiliki citra tubuh negatif. Di antara subjek yang bercitra tubuh negatif, 89 orang merasa gemuk meskipun sebenarnya hanya 35 orang yang benar-benar gemuk berdasarkan status gizi aktualnya. Lebih lanjut, Tabel 3 menampilkan hasil analisis ChiSquare bahwa adanya hubungan bermakna antara status gizi dengan citra tubuh $(\mathrm{p}<0,05)$ dengan nilai $\mathrm{OR}=1,3$. Artinya, seseorang dengan status gizi lebih berisiko 1,3 kali lebih besar untuk memiliki citra tubuh negatif dibandingkan dengan seseorang yang memiliki status gizi normal. Variabel rasa percaya diri juga berhubungan bermakna dengan citra tubuh $(\mathrm{p}<0,05)$. Pada faktor lingkungan, hanya variabel tingkat sosial ekonomi keluarga dengan citra tubuh yang menunjukkan hubungan bermakna secara statistik ( $\mathrm{p}<0,05)$.

Analisis multivariat dilakukan pada variabel yang memiliki nilai $p<0,25$, yaitu status gizi, rasa percaya diri, sosial ekonomi keluarga, dan dukungan sosial pada aspek kepuasan (Tabel 4). Hasil menunjukkan bahwa pada model pertama, variabel yang memiliki nilai p paling jauh dari signifikan adalah sosial ekonomi keluarga sehingga pada model selanjutnya variabel ini dieliminasi. Variabel status gizi memiliki nilai nol (0) dalam tabulasi
Tabel 1. Karakteristik subjek

\begin{tabular}{|c|c|c|}
\hline Variabel & n (142) & $\%$ \\
\hline \multicolumn{3}{|l|}{ Usia (tahun) } \\
\hline $15-17$ & 116 & 81,7 \\
\hline $18-19$ & 26 & 18,3 \\
\hline \multicolumn{3}{|l|}{ Daerah asal } \\
\hline Jawa & 89 & 62,7 \\
\hline Sumatra & 28 & 19,7 \\
\hline Kalimantan & 14 & 9,9 \\
\hline Maluku & 5 & 3,5 \\
\hline Nusa Tenggara & 5 & 3,5 \\
\hline Papua & 1 & 0,7 \\
\hline \multicolumn{3}{|l|}{ Pekerjaan ayah } \\
\hline Dokter & 2 & 1,4 \\
\hline Tidak bekerja/ pensiun & 5 & 3,5 \\
\hline Wirausaha & 9 & 6,3 \\
\hline Buruh/ petani & 14 & 9,9 \\
\hline Guru & 14 & 9,9 \\
\hline PNS & 14 & 9,9 \\
\hline Pegawai swasta & 84 & 59,1 \\
\hline \multicolumn{3}{|l|}{ Pekerjaan ibu } \\
\hline Petani & 3 & 2,1 \\
\hline Bidan/ dokter & 3 & 2,1 \\
\hline PNS & 5 & 3,5 \\
\hline Wirausaha & 10 & 7,0 \\
\hline Guru & 16 & 11,3 \\
\hline Ibu Rumah Tangga & 84 & 59,2 \\
\hline \multicolumn{3}{|l|}{ Pendidikan ayah } \\
\hline Tamat SD & 2 & 5,6 \\
\hline Tamat SMP & 10 & 7,0 \\
\hline Tamat SMA & 64 & 45,0 \\
\hline Diploma/ Sarjana & 66 & 46,4 \\
\hline \multicolumn{3}{|l|}{ Pendidikan ibu } \\
\hline Tamat SD & 10 & 7,0 \\
\hline Tamat SMP & 13 & 9,2 \\
\hline Tamat SMA & 59 & 41,5 \\
\hline Diploma/ Sarjana & 60 & 42,3 \\
\hline \multicolumn{3}{|l|}{ Status gizi } \\
\hline Gizi Lebih & 35 & 24,6 \\
\hline Gizi Normal & 107 & 75,4 \\
\hline Gizi Kurang & 0 & 0 \\
\hline
\end{tabular}

Tabel 2. Citra tubuh dibandingkan status gizi aktual

\begin{tabular}{|c|c|c|c|c|c|c|}
\hline \multirow{4}{*}{$\begin{array}{c}\text { Status gizi } \\
\text { aktual }\end{array}$} & \multicolumn{6}{|c|}{ Citra tubuh } \\
\hline & \multicolumn{4}{|c|}{ Negatif } & \multirow{2}{*}{\multicolumn{2}{|c|}{$\begin{array}{c}\text { Positif } \\
\text { Merasa } \\
\text { normal }\end{array}$}} \\
\hline & \multicolumn{2}{|c|}{$\begin{array}{c}\text { Merasa } \\
\text { gemuk }\end{array}$} & \multicolumn{2}{|c|}{$\begin{array}{c}\text { Merasa } \\
\text { kurus }\end{array}$} & & \\
\hline & $\mathbf{n}$ & $\%$ & $\mathbf{n}$ & $\%$ & $\mathbf{n}$ & $\%$ \\
\hline Gizi lebih & 35 & 100 & 0 & 0 & 0 & 0 \\
\hline Gizi normal & 54 & 50,5 & 25 & 23,3 & 28 & 26,2 \\
\hline Total & 89 & 62,7 & 25 & 17,6 & 28 & 19,7 \\
\hline
\end{tabular}


Tabel 3. Hubungan faktor individu dan lingkungan dengan citra tubuh

\begin{tabular}{|c|c|c|c|c|c|c|c|c|}
\hline \multirow{3}{*}{ Variabel } & \multicolumn{4}{|c|}{ Citra tubuh } & \multirow{3}{*}{$\mathrm{X}^{2}$} & \multirow{3}{*}{$\mathbf{p}$} & \multirow{3}{*}{ OR } & \multirow{3}{*}{$95 \% \mathrm{CI}$} \\
\hline & \multicolumn{2}{|c|}{ Negatif } & \multicolumn{2}{|c|}{ Positif } & & & & \\
\hline & $\mathbf{n}$ & $\%$ & $\mathbf{n}$ & $\%$ & & & & \\
\hline \multicolumn{9}{|l|}{ Faktor individu } \\
\hline \multicolumn{9}{|l|}{ Status gizi } \\
\hline Gizi lebih & 35 & 100 & 0 & 0 & 11,4 & $0,001^{*}$ & 1,3 & $1,21-1,52$ \\
\hline Gizi normal & 79 & 73,8 & 28 & 26,2 & & & & \\
\hline \multicolumn{9}{|l|}{ Pengetahuan gizi } \\
\hline Kurang & 71 & 78,9 & 19 & 21,1 & 0,3 & 0,583 & 0,9 & $0,81-1,12$ \\
\hline Baik & 43 & 82,7 & 9 & 17,3 & & & & \\
\hline \multicolumn{9}{|l|}{ Rasa percaya diri } \\
\hline Rendah & 31 & 86,1 & 5 & 13,9 & 30,2 & $0,000^{*}$ & - & - \\
\hline Normal & 76 & 88,4 & 10 & 16,6 & & & & \\
\hline Tinggi & 7 & 35,0 & 13 & 65,0 & & & & \\
\hline \multicolumn{9}{|c|}{ Faktor lingkungan } \\
\hline \multicolumn{9}{|l|}{ Budaya } \\
\hline \multicolumn{9}{|l|}{ Suku ayah } \\
\hline Jawa & 71 & 80,7 & 17 & 19,3 & 0,0 & 0,878 & 1,0 & $0,85-1,20$ \\
\hline Non Jawa & 43 & 79,6 & 11 & 20,4 & & & & \\
\hline \multicolumn{9}{|l|}{ Suku ibu } \\
\hline Jawa & 75 & 80,6 & 18 & 19,4 & 0,0 & 0,881 & 1,0 & $0,85-1,20$ \\
\hline Non Jawa & 39 & 79,6 & 10 & 20,4 & & & & \\
\hline \multicolumn{9}{|c|}{ Sosial ekonomi keluarga } \\
\hline Rendah & 3 & 42,9 & 4 & 57,1 & 7,2 & $0,028 *$ & - & - \\
\hline Sedang & 79 & 84,0 & 15 & 16,0 & & & & \\
\hline Tinggi & 32 & 78,0 & 9 & 22,0 & & & & \\
\hline \multicolumn{9}{|l|}{ Dukungan sosial } \\
\hline \multicolumn{5}{|c|}{ Aspek banyaknya pemberi dukungan sosial } & 0,7 & 0,400 & 0,9 & $0,78-1,09$ \\
\hline Sedikit & 85 & 78,7 & 23 & 21,3 & & & & \\
\hline Banyak & 29 & 85,3 & 5 & 14,7 & & & & \\
\hline \multicolumn{5}{|c|}{ Aspek kepuasan dukungan sosial ${ }^{1}$} & 2,1 & 0,227 & 0,8 & $0,49-1,23$ \\
\hline Tidak puas & 7 & 63,6 & 4 & 36,4 & & & & \\
\hline Puas & 107 & 81,7 & 24 & 18,3 & & & & \\
\hline
\end{tabular}

silang pada uji Chi-Square sehingga uji multivariat menunjukkan nilai $\mathrm{p}$ tak hingga. Namun, secara otomatis dengan metode backward variabel ini tetap dilanjutkan pada model kedua karena nilai signifikansi dengan menghilangkan syarat uji multivariat untuk variabel ini menunjukkan hasil bermakna $(p<0,05)$. Pada model kedua, seluruh variabel yang diuji signifikan $(p<0,05)$ sehingga diketahui bahwa variabel yang berhubungan secara bermakna dengan citra tubuh adalah status gizi, rasa percaya diri, dan dukungan sosial pada aspek kepuasan. Selain itu, berdasarkan nilai OR diketahui bahwa remaja putri dengan rasa percaya diri yang rendah memiliki risiko 21 kali lebih besar untuk memilki citra tubuh yang negatif dibandingkan dengan seseorang yang memiliki rasa percaya diri yang tinggi.

\section{BAHASAN}

Hasil penelitian menunjukkan bahwa sebagian besar subjek $(80,3 \%)$ menilai tubuhnya secara negatif dan pada subjek dengan citra tubuh negatif tersebut sebagian besar $(62,7 \%)$ merasa gemuk. Sejumlah 89 orang yang merasa gemuk, 54 orang diantaranya $(60,1 \%)$ sesungguhnya memiliki status gizi normal. Penelitian di Jepang pada perempuan usia dewasa awal menunjukkan hasil serupa yaitu dari 232 subjek 
Tabel 4. Analisis regresi logistik faktor-faktor yang mempengaruhi citra tubuh

\begin{tabular}{|c|c|c|c|c|}
\hline Model & Variabel & Koefisien (B) & $\mathbf{p}$ & OR $(95 \%$ CI $)$ \\
\hline \multirow[t]{10}{*}{ Model 1} & Status gizi & 20,275 & $0,000^{1}$ & - \\
\hline & Rasa percaya diri & & 0,000 & - \\
\hline & Rendah & 3,193 & 0,001 & $24,4(3,90-148,40)$ \\
\hline & Normal & 2,898 & 0,000 & $18,1(4,60-71,29)$ \\
\hline & Tinggi & & & \\
\hline & Sosial ekonomi keluarga & & 0,345 & - \\
\hline & Rendah & $-1,507$ & 0,149 & $0,221(0,03-1,70)$ \\
\hline & Sedang & $-0,281$ & 0,659 & $0,755(0,20-2,63)$ \\
\hline & Tinggi & & & \\
\hline & $\begin{array}{l}\text { Dukungan sosial aspek } \\
\text { kepuasan dukungan }\end{array}$ & $-1,495$ & 0,051 & $0,143(0,20-1,01)$ \\
\hline \multirow[t]{6}{*}{ Model 2} & Status gizi & 20,405 & $0,000^{1}$ & - \\
\hline & Rasa percaya diri & & 0,000 & - \\
\hline & Rendah & 3,058 & 0,000 & $21,3(3,97-114,3)$ \\
\hline & Normal & 2,855 & 0,000 & $17,6(4,71-65,6)$ \\
\hline & Tinggi & & & \\
\hline & $\begin{array}{l}\text { Dukungan sosial aspek } \\
\text { kepuasan dukungan }\end{array}$ & $-1,943$ & 0,044 & $0,143(0,02-0,95)$ \\
\hline
\end{tabular}

${ }^{1}$ signifikansi dari uji multivariat tanpa syarat karena terdapat tabel bernilai nol

yang merasa gemuk, 6 orang $(2,6 \%)$ diantaranya justru berstatus gizi kurus dan sebagian besar $(92,2 \%)$ berstatus gizi normal sedangkan yang benar-benar gemuk hanya 12 orang atau 5,2\% (20). Hasil penelitian ini juga sejalan dengan teori yang menyatakan bahwa pada usia remaja, seseorang cenderung memiliki citra tubuh negatif (21). Pada tingkatan usia remaja, terutama untuk remaja putri, seseorang memiliki kecenderungan memerhatikan bentuk tubuhnya karena pada usia ini penampilan merupakan hal penting dalam membangun rasa percaya diri (22).

Pada subjek yang memiliki status gizi lebih, seluruhnya $(100 \%)$ memiliki citra tubuh yang negatif. Hubungan yang bermakna antara status gizi dengan citra tubuh juga didapatkan dalam penelitian ini. Hal ini sesuai dengan penelitian pada remaja putri di Australia yang menunjukkan bahwa terdapat hubungan status gizi dengan citra tubuh. Penelitian tersebut mengungkapkan bahwa simpanan lemak yang tinggi menunjukkan adanya citra tubuh negatif (23). Pada penelitian ini diketahui bahwa seseorang dengan status gizi lebih memiliki risiko lebih besar untuk memiliki citra tubuh negatif sebesar 1,3 kali dibandingkan dengan seseorang yang memiliki status gizi normal. Seseorang dengan status gizi lebih berisiko 10 kali lebih besar untuk memiliki keinginan menurunkan berat badan (24).
Hasil penelitian menunjukkan 90 orang subjek $(63,4 \%)$ memiliki pengetahuan gizi yang kurang. Hubungan pengetahuan gizi dengan citra tubuh pun menunjukkan hasil tidak bermakna. Jawaban subjek terhadap beberapa butir pertanyaan kuesioner menunjukkan hanya $19 \%$ subjek yang mengetahui jenis bahan makanan sumber energi. Selain itu, kurang dari separuh $(48,6 \%)$ subjek tidak mengetahui jenis makanan selingan yang tidak baik bagi kesehatan apabila dimakan berlebihan. Kurangnya pengetahuan subjek dapat disebabkan terbatasnya materi ilmu gizi yang disampaikan dalam kurikulum di sekolah, di samping proporsi pembelajaran di madrasah/pesantren lebih besar pada materi keagamaan meskipun ICBB memiliki program Ilmu Pengetahuan Alam (IPA) yang juga mengajarkan ilmu biologi dan kimia.

Hasil analisis menunjukkan bahwa faktor individu yang berupa rasa percaya diri berhubungan bermakna dengan citra tubuh. Subjek dengan rasa percaya diri yang tinggi cenderung memiliki citra tubuh positif. Hasil uji multivariat pada variabel ini juga menunjukkan hubungan bermakna dengan nilai OR yang menggambarkan bahwa remaja putri dengan rasa percaya diri yang rendah berisiko 21 kali untuk memiliki citra tubuh negatif dibandingkan dengan remaja yang rasa percaya dirinya 
tinggi. Hasil penelitian ini sejalan dengan studi yang menyimpulkan bahwa rasa percaya diri berhubungan dengan kepuasan tubuh (25). Penelitian lainnya juga memaparkan bahwa anak-anak usia 10-13 tahun dengan status gizi lebih memiliki nilai percaya diri yang lebih rendah dibandingkan dengan anak-anak dengan status gizi normal dalam berbagai aspek, termasuk kepercayaan diri atas penampilan fisik dan penerimaan sosial (26).

Lebih lanjut, diketahui bahwa sebagian besar subjek baik ayah ataupun ibu berasal dari suku Jawa dan hubungan suku ayah ataupun ibu dengan citra tubuh menunjukkan hasil tidak bermakna. Penelitian di Jakarta juga mengemukakan hal yang sama, bahwa tidak terdapat perbedaan bermakna antara apresiasi tubuh pada suku Jawa, Sunda, dan Cina. Hal ini terjadi karena suku-suku tersebut tinggal pada lingkungan yang sama sehingga saling memengaruhi (27). Suku orang tua memberikan pengaruh pada budaya, kebiasaan, serta gaya hidup, termasuk citra tubuh dan gambaran tubuh ideal. Namun, beberapa hasil studi terkait menunjukkan bahwa persepsi ini melibatkan aspek lingkungan lain seperti faktor sosial ekonomi, paparan media, persahabatan, dan kondisi geografis, serta faktor individu berupa harga diri, baik melalui pilihan pakaian, perawatan, dan gaya hidup $(28,29)$.

Hasil analisis bivariat menunjukkan bahwa sosial ekonomi keluarga berhubungan secara bermakna dengan citra tubuh. Sebanyak 4 dari 7 orang subjek yang berstatus sosial ekonomi rendah memiliki citra tubuh positif. Hubungan yang bermakna ini sejalan dengan penelitian sebelumnya yang menyatakan bahwa status sosial ekonomi dengan citra tubuh memiliki hubungan yang signifikan (30). Status sosial ekonomi berhubungan dengan citra tubuh kemungkinan karena subjek dengan tingkat sosial ekonomi yang lebih tinggi memiliki akses dan preferensi terhadap makanan lebih banyak dengan menambah makanan selingan dari kantin atau selain makanan yang disediakan oleh asrama. Namun, analisis multivariat menunjukkan hubungan yang tidak bermakna pada variabel ini sehingga status sosial ekonomi tidak masuk dalam model analisis lanjutan seperti halnya status gizi, rasa percaya diri, dan kepuasan dukungan sosial yang secara bersama-sama dapat memprediksi citra tubuh santriwati. Subjek penelitian ini berasal dari populasi yang homogen, yaitu semua santri putri makan pada jam yang sama, dengan jenis makan yang sama, dan porsi yang cenderung sama. Santri memiliki jadwal kegiatan yang cukup padat. Pihak asrama dan sekolah (ICBB) telah menyusunkan jadwal kegiatan santri dari jam bangun pagi hingga jam tidur malam dan akses ke luar yang terbatas. Keseragaman dalam jadwal, program, dan pelajaran pada sekolah asrama membentuk perilaku dan gaya hidup yang cenderung sama. Penelitian pada sekolah asrama di Taiwan menyatakan bahwa siswa pada sekolah asrama memiliki citra tubuh yang lebih negatif dibandingkan siswa non-asrama karena siswa pada sekolah asrama berbagi bersama dengan temantemannya dalam hal kamar, tempat makan, dan kamar mandi umum sehingga mereka memiliki privasi yang terbatas. Akibatnya, siswa lebih cenderung memiliki citra tubuh yang negatif (31).

Variabel dukungan sosial ditinjau melalui dua aspek, yaitu secara kuantitatif berupa aspek banyaknya pemberi dukungan dan secara kualitatif berupa aspek kepuasan dukungan, yang keduanya menunjukkan hubungan tidak bermakna dengan citra tubuh. Meskipun demikian, dukungan sosial pada aspek kepuasan dukungan menunjukkan nilai $\mathrm{p}<0,25$ sehingga memenuhi syarat untuk dilakukan uji multivariat. Hasil uji multivariat menunjukkan rasa puas terhadap dukungan sosial berhubungan bermakna dengan citra tubuh $(p<0,05)$. Hal ini sesuai dengan penelitian yang menyebutkan bahwa dukungan sosial secara kualitatif menunjukkan hubungan yang bermakna dengan citra tubuh tetapi dukungan sosial secara kuantitatif dengan citra tubuh menunjukkan hubungan yang tidak bermakna (19). Penelitian pada 279 orang mahasiswa ras Latin usia dewasa awal menyebutkan bahwa kepuasan dukungan sosial (social support) yang tinggi berkorelasi dengan kepuasan terhadap citra tubuh sedangkan rasa kebersamaan seseorang (collectivism) dengan kepuasan tubuh tidak memiliki hubungan yang bermakna (32).

\section{SIMPULAN DAN SARAN}

Terdapat hubungan bermakna antara faktor individu yaitu status gizi dan rasa percaya diri dengan citra tubuh, serta antara faktor lingkungan berupa sosial 
ekonomi dan dukungan sosial pada aspek kualitas atau kepuasan dukungan dengan citra tubuh pada santri putri. Status gizi bersama-sama dengan faktor lain yaitu rasa percaya diri dan kepuasan dukungan sosial berpengaruh terhadap citra tubuh santri putri. Pengetahuan gizi tidak berhubungan dengan citra tubuh tetapi masih tergolong kurang pada sebagian besar subjek, khususnya dalam hal sumber-sumber zat gizi dan makanan selingan.

Pihak pondok pesantren putri disarankan untuk memfasilitasi santri dengan program penyuluhan atau tambahan mata pelajaran pendidikan jasmani, olahraga, dan kesehatan, dengan materi mengenai tumbuh kembang remaja, gaya hidup sehat, dan gizi seimbang. Di samping itu, diperlukan adanya edukasi oleh pihak Unit Kesehatan Pondok (UKP) mengenai berat badan ideal ketika santri melakukan penimbangan berat badan dan tinggi badan. Pihak pondok pesantren juga diharapkan memberikan himbauan kepada wali santri melalui pengumuman tertulis agar wali atau keluarga mendukung pola hidup sehat dengan mengarahkan remaja putrinya dalam membelanjakan uang saku untuk membeli makanan jajanan yang sehat.

\section{Pernyataan konflik kepentingan}

Tidak ada konflik kepentingan dalam penelitian ini.

\section{RUJUKAN}

1. Fauzi CA. Pengetahuan dan perilaku gizi seimbang menurut pesan ke-6, 10, 11, 12 dari Pedoman Umum Gizi Seimbang (PUGS) pada remaja. Jurnal Kesehatan Reproduksi 2012;3(2):91-105.

2. Mcguire M, Beerman KA. Nutritional sciences: from fundamentals to food. Belmont: Wadsworth; 2011.

3. Santrock JW. Perkembangan masa hidup jilid 1. Jakarta: Penerbit Erlangga; 2011.

4. Vonderen KEV, Kinnally W. Media effects on body image: examining media exposure in the broader context of internal and other social factors. American Communication Journal 2012;14(2):41-57.

5. Lefaan P. Hubungan antara faktor lingkungan, citra tubuh dan diet penurunan berat badan pada remaja putri di SMA di Distrik Abepura Kota Jayapura [Tesis]. Yogyakarta: Universitas Gadjah Mada; 2012.

6. Rusello S. The impact of media exposure on self-esteem and body satisfaction in men and women. Journal of Interdisciplinary Undergraduate Research 2009:1(4):1-13.
7. Feist J, Feist GJ. Theories of personality. Yogyakarta: Pustaka Pelajar; 2006.

8. Wang D, Shi Y, Chang C, Stewart D, Ji Y, Harris N, et al. Knowledge, attitudes and behaviour regarding nutrition and dietary intake of seventh-grade students in rural areas of Mi Yun County, Beijing, China. Environ Health Prev Med 2014;19(3):179-86.

9. Tarigan N, Hadi H, Julia M. Hubungan citra tubuh dengan status obesitas, aktivitas fisik, dan asupan energi remaja SLTP di Kota Yogyakarta dan Kabupaten Bantul. Jurnal Gizi Klinik Indonesia 2005;1(3):130-6.

10. Sulistyan A, Huriyati E, Hastuti J. Distorsi citra tubuh, perilaku makan dan fad diet pada remaja putri di Yogyakarta. Jurnal Gizi Klinik Indonesia 2016;12(3):99-107.

11. Fitria N, Sudargo T, Huriyati E. Hubungan ketidakpuasan citra tubuh dan perilaku makan dengan status gizi santri di Pondok Pesantren Mubtadi Aat, Lirboyo, Kediri [Tesis]. Yogyakarta: Universitas Gadjah Mada; 2016.

12. Sudrajat SS, Sinaga T. Analisis biaya makan terhadap ketersediaan makanan serta tingkat kecukupan gizi santri di Pondok Pesantren Darul Arqam Garut. Gizi Indon 2016;39(2):115-24.

13. Rokhmah F, Muniroh L, Nindya TS. Hubungan tingkat kecukupan energi dan zat gizi makro dengan status gizi siswi SMA di Pondok Pesantren AL-Izzah Kota Batu. Media Gizi Indones 2017;11(1):94-100.

14. Sya'bani IRN, Sumarmi S. Hubungan status gizi dengan kejadian anemia pada santriwati di Pondok Pesantren Darul Ulum Peterongan Jombang. Jurnal Keperawatan Muhammadiyah 2016;1(1):7-15.

15. Emilia E. Pengembangan alat ukur pengetahuan, sikap dan praktek gizi pada remaja [Tesis]. Bogor: Institut Pertanian Bogor; 2008.

16. Larasati WP. Meningkatkan self esteem melalui metode self instruction [Tesis]. Jakarta: Universitas Indonesia; 2012.

17. Istafada A. Hubungan antara status sosial ekonomi dengan perilaku hidup bersih dan sehat (PHBS) pada siswa di SD Muhammadiyah Senggotan Kecamatan Kasihan Kabupaten Bantul [Skripsi]. Yogyakarta: Universitas Gadjah Mada; 2010.

18. Hastoro D. Hubungan dukungan sosial teman sebaya dengan derajat depresi pada siswa sekolah dasar negeri di Kota Yogyakarta [Skripsi]. Yogyakarta: Universitas Gadjah Mada; 2011.

19. Habibah N. Hubungan paparan korean wave melalui media informasi dengan body image dan risiko eating disorder pada remaja putri SMA Kota Yoygakarta [Skripsi]. Yogyakarta: Universitas Gadjah Mada; 2014.

20. Mase T. Influences of peers' and family members' body shapes on perception of body image and desire for 
thinness in Japanese female students. Int J Womens Health 2015;24(7):625-33.

21. Norton K, Olds T. Anthropometrica: a textbook of body measurement for sports and health courses. Adelaide: UNSW Press; 2004.

22. Tarwoto, dkk. Kesehatan remaja problem dan solusinya. Jakarta: Salemba Medika; 2010.

23. Lubans DR, Cliff DP. Muscular fitness, body composition and physical self-perception in adolescents. J Sci Med Sport 2011;14(3):216-21.

24. Pelegrini A, Coquiero Rda S, Beck CC, Ghedin KD, Lopes Ada S, Petroski EL. Dissatisfaction with body image among adolescent students: association with sociodemographic factors and nutritional status. Ciên Saúde Colet 2014;19(4):1201-8.

25. Wichstrom L, von Soest T. Reciprocal relations between body satisfaction and selfesteem: a large 13-year prospective study of adolescents. J Adolesc 2016;47:1627.

26. Danielsen YS, Stormark KM, Nordhus IH, Mæhle M, Pallesen S, et al. Factors associated with low self-esteem in children with overweight. Obes Fact 2012;5(5):722-33.
27. Swami V, Jaafar JL. Factor structure of the body appreciation scale among indonesian women and men: further evidence of a two-factor solution in a non-western population. Body Image 2012;9(4):539-42.

28. Helfert S, Warschburger P. The face of appearance-related sosial pressure: gender, age and body mass variations in peer and parental pressure during adolescence. Child Adolesc Psychiaty Ment Health 2013;7(1):16.

29. Tiggemann M. Considerations of positive body image across various social identitiesand special populations. Body Image 2015;14:168-76.

30. van den Berg PA, Mond J, Eisenberg M, Ackard D, Neumark-Sztainer D. The link between body dissatisfaction and self-esteem in adolescents: similarities across gender, age, weight status, race/ethnicity, and socioeconomic status. J Adolesc Health 2010;47(3):290-6.

31. Chang CT, Garg P, Giddon DB. Boarding school influence on self-reported concern for body and face morphology. Asian J Psychiatr 2016;22:96-101.

32. Cordero ED. Self-esteem, social support, collectivism, and the thin-ideal in Latina College Undergraduates. Body Image 2011;8(1):82-5. 